\title{
METHOD FOR DETERMINING CONSUMER HEAT ENERGY DEMAND PROFILE USING HEAT CONSUMPTION DATA FROM PREVIOUS PERIODS
}

\author{
Raimunds Selegovskis, Janis Berzins \\ Latvia University of Life Sciences and Technologies, Latvia \\ raimunds.selegovskis@1lu.lv, berzs11@inbox.lv
}

\begin{abstract}
The European targets in energy sector are included in the program 20-20-20. It means that in 2020 the energy goals are to have $20 \%$ reduction in greenhouse gas emissions compared to the 1990 levels, $20 \%$ energy coming from renewable sources and $20 \%$ increasing in energy efficiency. Thus, it is very important to optimize the operation of building heat supply systems to reach the mentioned goals, the third goal connected also to the first goal. Calculation of the demanded heat power of a building's heating system at certain outdoor air temperature and certain time is essential for efficiency estimations, technical solutions and set-up of parameters in customers' internal heating and supplier's external heat supply systems. The heat power demand of a certain consumer is a combination of the power needed for premises heating, the power for hot domestic water (HDW) production and heat losses in the consumer's internal system. Average heat power, which can be easily calculated from annual or monthly consumption data, does not describe the system precisely and there is not enough information for tuning the system's parameters accordingly, thus additional calculations must be done. This paper describes a method of how to determine the consumers' heat power demand profile using the data of consumed heat energy in previous periods and also gives the example of the power demand profile determined for the consumers connected to the central heating grid in Ozolnieki, Latvia. This method is useful for preliminary calculations and provides sufficient accuracy for power estimations. The overall result of accurate set-up of the systems' parameters is decrease of heat losses in the heat supply grid, less emissions for heat production and also it has an economic effect.
\end{abstract}

Keywords: heat energy, hot domestic water (HDW), demand profile.

\section{Introduction}

The efficiency of a central heating system is determined by calculating the total thermal energy delivered to the consumers as a fraction of total thermal energy introduced into the central heating grid. Naturally heat loses will occur, since there is a temperature difference between the pipes and their surrounding, but this can be minimized, if the heat power introduced into the central heating system is just enough to cover the losses and the demanded power.

When adjustments are done in central heating system parameters, it is based on the calculated heat power demand of connected buildings heat loses to maintain comfort temperature and heat power for prepared HDW, if it is needed. Calculations are based on thermal conductivity of materials and the assumed HDW consumption of a building, but this does not describe the situation precisely, because the actual consumption data can be different and vary from building to building. Habits, age, occupation and other characteristics of buildings' inhabitants, location and their surroundings can affect heat consumption in a great deal. Yao R. and Steemers K. in the paper "A method for formulating energy load profile for domestic buildings in the UK" also suggest that energy consumption is affected by inhabitants' peculiarities and habits, but their approach is based on overall statistics and not on actual energy consumption of a specific building [4]. This kind of approach is suited for buildings that are not built yet, or if there are no available data. Actual energy consumption data already include all possible oddities of a specific building, so there is no need for more detailed analysis.

The tune up of internal and external heat supply systems obtains the highest precision, if the actual building's consumption profile is taken into the consideration and adjustments are done accordingly. This minimizes overheating and heat losses.

The objective of this paper is to describe the method based on the algorithm of calculations to determine the heat demand profile of the consumers according to the outside temperature and time of the day, to acquire reasonable data that can be used to set up the heat supply systems properly.

\section{Materials and methods}

Every heat supply service company that holds a central heating grid of pipelines has a number of clients connected to it and to precisely calculate the amount of consumed energy heat-meters are 
integrated in every connection line to a client. This is not only a good practice, but it is also stated in the regulation No. 876 "Regulations Regarding the Supply and Use of Thermal energy" issued by the Cabinet of Ministers. This means that every heat supply company must hold data of the consumed energy.

To develop this algorithm the data of Ozolnieki municipality central heating system consumers were explored and analyzed. The provided data by the heat supply service company Ozolnieki KSDU Ltd describe monthly heat consumption of 35 customers in 2017.Ozolnieku KSDU Ltd provides heat supply services to 19 multiple apartments, 2 private and 14 public houses and institutions.

Ozolnieki KSDU Ltd uses heat-meters with ultrasound flow meters and immersible temperature sensors, which provides high precision of the metered heat carrier flow and its supply and return temperatures, thus also the consumed energy. Registration of the consumed amounts of energy and water is done manually by reading the meter at the end of every period. The outside temperature was measured at the Ozolnieki KSDU Ltd boilerhouse at Zemgales street 2. The temperature was recorded once an hour and was measured by the DISTECH CONTROLS TT331 A type sensor with precision $\pm 0.2{ }^{\circ} \mathrm{C}$ at $25^{\circ} \mathrm{C}[1]$.

To calculate the heat power needed for HDW service, it is important to understand, that the heat capacity needed to prepare and use hot water depends not only on the amount of hot water consumed, but also on the parameters of the circulation line and towel dryers, it is assumed that during summer all heat spent by consumers is used to prepare and use hot water. The required heat output can be calculated from this parameter.

The average capacity of each consumer was calculated using the amounts of the consumed thermal energy during the period, when heat is used only for hot water preparation and circulation $\left(1^{\text {st }}\right.$ of June to $30^{\text {th }}$ of September):

$$
Q_{h W a}=\frac{\sum E_{H}}{t}
$$

where $Q_{h W a}$ - average power to prepare hot water and to cover circulation heat losses, W;

$E_{H}$ - heat energy consumed during summer months, Wh;

$t$-duration of the period, $\mathrm{h}$.

The results of calculations are given in Table 1.

Average power for hot water preparation and compensation of circulation heat losses $Q_{h W a}$

\begin{tabular}{|c|c|c|c|c|c|}
\hline Consumer & $\begin{array}{c}\text { Therma } \\
\text { l energy } \\
\text { June, } \\
\text { MWh }\end{array}$ & $\begin{array}{c}\text { Thermal } \\
\text { energy } \\
\text { July, } \\
\text { MWh }\end{array}$ & $\begin{array}{c}\text { Thermal } \\
\text { energy } \\
\text { August, } \\
\text { MWh }\end{array}$ & $\begin{array}{c}\text { Thermal } \\
\text { energy } \\
\text { September, } \\
\text { MWh }\end{array}$ & $\begin{array}{c}\text { Average } \\
\text { power } \\
\text { for } \\
\text { HDW, } \\
\text { kW }\end{array}$ \\
\hline Apartment buildings Nr. 1-19 & 116.57 & 111.3 & 108.8 & 115.49 & 154.45 \\
\hline Institution buildings Nr. 1-14 & 59.62 & 81.42 & 74.67 & 103.46 & 109.00 \\
\hline Total & $\mathbf{1 7 6 . 1 9}$ & $\mathbf{1 9 2 . 7 2}$ & $\mathbf{1 8 3 . 4 7}$ & $\mathbf{2 1 8 . 9 5}$ & $\mathbf{2 6 3 . 4 3}$ \\
\hline
\end{tabular}

The average power demanded by users for HDW service is calculated at $263.43 \mathrm{~kW}$.

The average power, however, does not fully describe the profile of the capacity needed to prepare and circulate hot water, since the consumption of hot water in buildings is non-linear and mainly depends on the time of the day. Further calculations assume that the heat capacity required for hot water preparation and circulation is independent of outdoor air temperature.

In order to adjust the heat capacity needed for hot water preparation and use, depending on the time of the day, the hot water consumption profiles of multi-apartment buildings, describing the average hourly consumption of hot water (Table 2 HDW consumption profile), can be used. Although some of the users connected to the Ozolnieki KSDU Ltd grid are not multi-apartment houses, further 
calculations assume that the profile of the use of HDW for all consumers is identical, regardless of the day of the week or the type of the user.

The highest HDW consumption is observed in the mornings and evenings of working days from 7:00-9:00 and 17:00-19:00, while the lowest -in the hours of the night from 02:00 to 6:00. Using average power and adjusting it depending on the profile of HDW use, the capacity profile for HDW preparation and circulation was calculated and compiled (Table2 ).

Table 2

Calculated heat power required for hot domestic water preparation and circulation

\begin{tabular}{|c|c|c|c|c|}
\hline $\begin{array}{l}\text { Time of } \\
\text { the day }\end{array}$ & $\begin{array}{c}\text { HDW } \\
\text { consumption } \\
\text { profile [2], I }\end{array}$ & $\begin{array}{c}\text { Proportio } \\
\text { n against } \\
\text { total }\end{array}$ & $\begin{array}{c}\text { Proportion } \\
\text { against } \\
\text { average } \\
\end{array}$ & $\begin{array}{l}\text { Power for } \\
\text { HDW, kW }\end{array}$ \\
\hline $00: 00$ & 291.7 & $6 \%$ & $145 \%$ & 381.65 \\
\hline 01:00 & 59.4 & $1 \%$ & $30 \%$ & 77.72 \\
\hline 02:00 & 29.7 & $1 \%$ & $15 \%$ & 38.86 \\
\hline 03:00 & 25.3 & $1 \%$ & $13 \%$ & 33.10 \\
\hline 04:00 & 25.4 & $1 \%$ & $13 \%$ & 33.23 \\
\hline 05:00 & 25.3 & $1 \%$ & $13 \%$ & 33.10 \\
\hline 06:00 & 37.8 & $1 \%$ & $19 \%$ & 49.46 \\
\hline $07: 00$ & 122.5 & $3 \%$ & $61 \%$ & 160.28 \\
\hline 08:00 & 371.3 & $8 \%$ & $184 \%$ & 485.80 \\
\hline 09:00 & 609.9 & $13 \%$ & $303 \%$ & 798.00 \\
\hline $10: 00$ & 587.6 & $12 \%$ & $292 \%$ & 768.80 \\
\hline 11:00 & 240.2 & $5 \%$ & $119 \%$ & 314.27 \\
\hline $12: 00$ & 138.1 & $3 \%$ & $69 \%$ & 180.67 \\
\hline 13:00 & 104.4 & $2 \%$ & $52 \%$ & 136.59 \\
\hline $14: 00$ & 220.7 & $5 \%$ & $110 \%$ & 288.76 \\
\hline $15: 00$ & 158.7 & $3 \%$ & $79 \%$ & 207.64 \\
\hline $16: 00$ & 371.2 & $8 \%$ & $184 \%$ & 485.67 \\
\hline $17: 00$ & 82.2 & $2 \%$ & $41 \%$ & 107.55 \\
\hline 18:00 & 117.3 & $2 \%$ & $58 \%$ & 153.47 \\
\hline $19: 00$ & 169.6 & $4 \%$ & $84 \%$ & 221.90 \\
\hline 20:00 & 230.7 & $5 \%$ & $115 \%$ & 301.84 \\
\hline $21: 00$ & 191.1 & $4 \%$ & $95 \%$ & 250.03 \\
\hline 22:00 & 178.4 & $4 \%$ & $89 \%$ & 233.41 \\
\hline $23: 00$ & 443.7 & $9 \%$ & $220 \%$ & 580.53 \\
\hline TOTAL & 4832.2 & & & \\
\hline $\begin{array}{c}\text { AVERAG } \\
\text { E } \\
\end{array}$ & 201.3 & & & \\
\hline
\end{tabular}

The calculation of the average heat power required for buildings heating purposes was carried out using the information provided by the merchant regarding the heating energy spent during a month by the consumer.

The average heating power was calculated:

$$
Q_{H a}=\frac{E_{T}}{t}-Q_{h W a}
$$

where $Q_{H a}-$ average heat power required for building heating purposes, W;

$E_{T}$ - monthly amount of consumed thermal energy, Wh;

$t$ - duration of the period, h.

Average monthly capacity required for heating is summarized in Table 3. 
Heat capacity required for building heating

\begin{tabular}{|c|c|c|c|}
\hline Period & $\begin{array}{c}\text { Thermal energy } \\
\text { consumption, } \\
\text { MWh }\end{array}$ & $\begin{array}{c}\text { Average } \\
\text { power, kW }\end{array}$ & $\begin{array}{c}\text { Average power } \\
\text { for heating, kW }\end{array}$ \\
\hline January & 1225 & 1645.95 & 1382.52 \\
\hline February & 1095 & 1629.35 & 1629.35 \\
\hline March & 845 & 1135.71 & 1135.71 \\
\hline April & 704 & 978.24 & 978.24 \\
\hline May & 364 & 488.82 & 488.82 \\
\hline October & 656 & 881.80 & 881.80 \\
\hline November & 846 & 1175.14 & 1175.14 \\
\hline December & 989 & 1329.22 & 1329.22 \\
\hline
\end{tabular}

Since the heat output required for building heating depends on the outdoor air temperature, which may vary significantly during the month, the average heating capacity needed does not fully describe the situation. The average hourly outdoor air temperature data maintained during the system monitoring are compared to the average outdoor air temperature of the month and shown in the graph in Fig. 1.

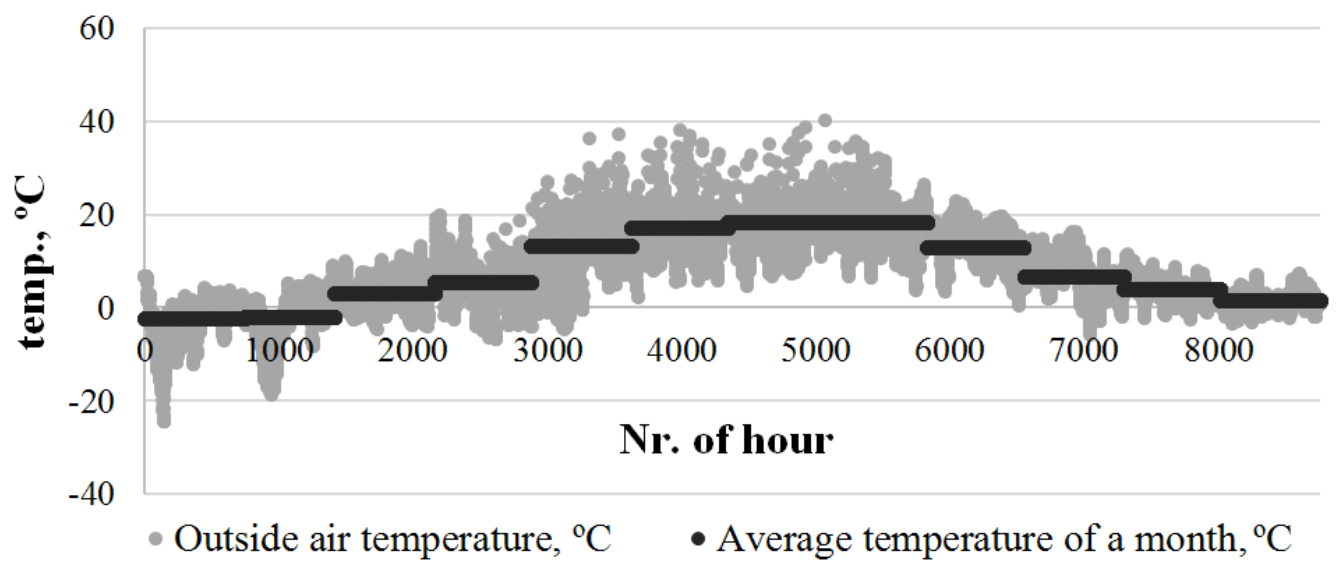

Fig. 1. Comparison of hourly and monthly average outdoor air temperatures

\section{Results and discussion}

To calculate the monthly average heat power, it is necessary to calculate the average hourly capacity. For the adjustment the coefficient referred to in Paragraph 35 of the Cabinet of Ministers Regulation No. 876 "Regulations for Supply and Use of Heat Energy" [3] shall be used. If the thermal energy meters are damaged or excluded for the purpose of carrying out repairs, checks, replacements, movements or other reasons, the amount of the thermal energy spent shall be determined on the basis of the average consumption during the period, when the heat meter was running and not less than three days. In that case, the amount of the heat consumed on heating and ventilation shall be multiplied by the coefficient $\mathrm{k}$. The average temperature of the period was used for the average temperature of the fixed hour, but the average outdoor air temperature of the month was used as the calculated temperature.

where $k$-adjustment factor;

$$
k=\frac{T_{i}-T_{h}}{T_{i}-T_{m}},
$$

$T_{i}$ - indoor air temperature, ${ }^{\circ} \mathrm{C}$;

$T_{h}$ - fixed average outdoor temperature hourly, ${ }^{\circ} \mathrm{C}$;

$T_{m}$ - fixed average outdoor temperature monthly, ${ }^{\circ} \mathrm{C}$. 
Since the average heat output is the energy-time ratio, but the time over the period is the same, the formula can also be used for heat power calculations.

An example of calculation of the heat power needed for heating is given in Table 4 .

Table 4

Example of calculation of hourly average heat capacity for heating

\begin{tabular}{|c|c|c|c|c|c|c|}
\hline Date and time & $\begin{array}{l}\text { Outdoor } \\
\text { temp., }{ }^{\circ} \mathrm{C}\end{array}$ & $\begin{array}{l}\text { Indoor } \\
\text { temp., }{ }^{\circ} \mathrm{C}\end{array}$ & $\begin{array}{l}\text { Average } \\
\text { outdoor } \\
\text { temp., }{ }^{\circ} \mathrm{C}\end{array}$ & $\begin{array}{l}\text { Adjustment } \\
\text { factor, } k\end{array}$ & $\begin{array}{c}\text { Average } \\
\text { power for } \\
\text { heating, } \\
\text { kW }\end{array}$ & $\begin{array}{c}\text { Adjusted } \\
\text { power for } \\
\text { heating, } \\
\text { kW }\end{array}$ \\
\hline 01.01.2017 00:00 & 6.5 & \multirow{6}{*}{18.0} & \multirow{6}{*}{-2.5} & 0.561 & \multirow{6}{*}{1382.52} & 775.56 \\
\hline $01.01 .201701: 00$ & 6.6 & & & 0.556 & & 768.82 \\
\hline 01.01.2017 02:00 & 6.5 & & & 0.561 & & 775.56 \\
\hline 01.01.2017 03:00 & 6.5 & & & 0.561 & & 775.56 \\
\hline 01.01.2017 04:00 & 6.5 & & & 0.561 & & 775.56 \\
\hline 01.01.2017 05:00 & 6.6 & & & 0.556 & & 768.82 \\
\hline
\end{tabular}

When calculating the heat output required for heating hours for 2017 and adding the calculated heat output required for hot water preparation and circulation, the hourly heat output profile requested by the consumers was drawn up (Fig. 2).

Due to the seasonal nature of heat consumption, the profile of the capacity demanded by the consumers also shows that the highest heat energy consumption is observed in winter months, but outside the heating season, only the capacity needed to prepare and circulate hot water is required.

The analysis of the profile of the heat output requested by the users has shown that the total required heat energy amounts to $7395 \mathrm{MWh}$ of heat energy. As the Ozolnieki KSDU Ltd data on the actual thermal energy consumption in 2017 show the total thermal energy spent by the users at $7495 \mathrm{MWh}$, the profile accuracy is of $98.67 \%$.

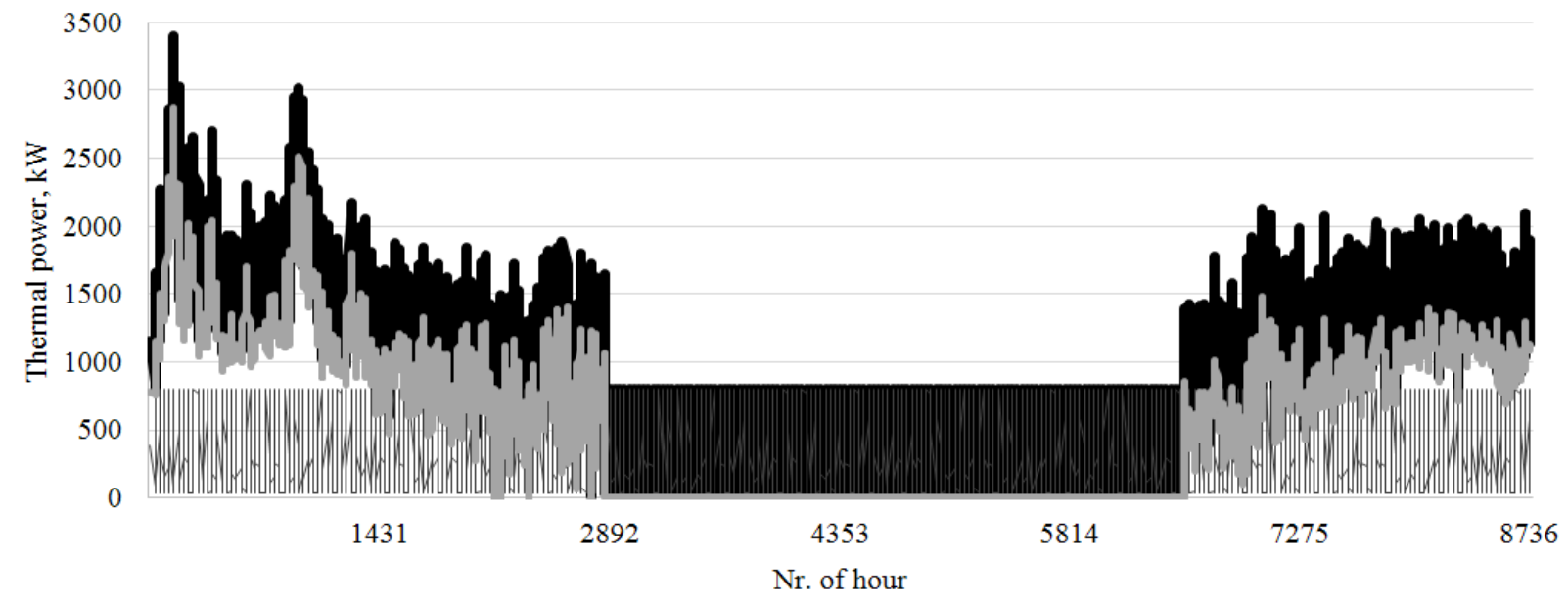

Total demanded power, $\mathrm{kW} \quad$ - Power for HDW, $\mathrm{kW} \quad$ Adjusted power for heating, $\mathrm{kW}$

Fig. 2. Consumer demanded heat capacity profile in $\mathbf{2 0 1 7}$

In order to determine the maximum heat output required by the consumers, the calculation was carried out using the heating energy used by the consumers during one month period. In order to describe the real situation more precisely, the amount of the thermal energy consumed during the month of January 2017 was used for the capacity calculation. In this month the average outdoor air temperature was the lowest, as well as the amount of the consumed thermal energy was the largest. The heat output required for heating was calculated using the average power, adjusted by the conversion factor. The heat capacity needed for hot water preparation and circulation has been considered to be constant and independent on the outdoor air temperature. The calculation used the maximum value calculated in the hot water profile. Mathematically summarizing the calculated 
capacity, the maximum demanded power at the outdoor air temperature $-20.7^{\circ} \mathrm{C}$ was obtained (Table 5).

The calculated heat power required by the users at the outdoor air temperature of $-20.7^{\circ} \mathrm{C}$ is $3410 \mathrm{~kW}$, although the sum of all thermal capacities of connections is $8173 \mathrm{~kW}$ (Table 5).

Table 5

Calculation of the maximum capacity requested by consumers

\begin{tabular}{|c|c|c|c|c|c|c|c|}
\hline \multicolumn{2}{|c|}{ Consumer } & $\begin{array}{c}\text { Average } \\
\text { power } \\
\text { for } \\
\text { HDW, } \\
\text { kW }\end{array}$ & $\begin{array}{c}\text { Max } \\
\text { HDW } \\
\text { power, } \\
\text { kW }\end{array}$ & $\begin{array}{c}\text { Average } \\
\text { power for } \\
\text { heating } \\
(\text { Jan), kW }\end{array}$ & $\begin{array}{c}\text { Max } \\
\text { power for } \\
\text { heating, } \\
\text { kW }\end{array}$ & $\begin{array}{c}\text { Max } \\
\text { total } \\
\text { power, } \\
\text { kW }\end{array}$ & $\begin{array}{c}\text { Thermal } \\
\text { capacity of } \\
\text { connection, } \\
\mathbf{k W}\end{array}$ \\
\hline \multirow{19}{*}{$\begin{array}{c}\text { Apartment } \\
\text { building } \\
\text { No. }\end{array}$} & 1 & 7.60 & 23.03 & 22.53 & 42.58 & 65.61 & 201.00 \\
\hline & 2 & 4.02 & 12.17 & 22.97 & 43.41 & 55.58 & 154.00 \\
\hline & 3 & 7.33 & 22.19 & 20.93 & 39.54 & 61.73 & 199.00 \\
\hline & 4 & 2.88 & 8.73 & 22.74 & 42.96 & 51.69 & 152.00 \\
\hline & 5 & 3.25 & 9.86 & 16.27 & 30.75 & 40.61 & 124.00 \\
\hline & 6 & 8.55 & 25.88 & 31.80 & 60.10 & 85.98 & 246.00 \\
\hline & 7 & 17.24 & 52.21 & 61.07 & 115.40 & 167.61 & 304.00 \\
\hline & 8 & 2.85 & 8.64 & 26.02 & 49.17 & 57.81 & 187.00 \\
\hline & 9 & 4.25 & 12.87 & 17.08 & 32.28 & 45.15 & 156.00 \\
\hline & 10 & 2.67 & 8.08 & 17.41 & 32.91 & 40.98 & 142.00 \\
\hline & 11 & 8.31 & 25.17 & 24.88 & 47.01 & 72.18 & 198.00 \\
\hline & 12 & 7.86 & 23.79 & 20.81 & 39.33 & 63.12 & 199.00 \\
\hline & 13 & 13.44 & 40.71 & 40.53 & 76.58 & 117.29 & 313.00 \\
\hline & 14 & 9.77 & 29.59 & 31.60 & 59.72 & 89.31 & 243.00 \\
\hline & 15 & 30.70 & 92.99 & 114.21 & 215.81 & 308.80 & 581.00 \\
\hline & 16 & 11.78 & 35.67 & 33.88 & 64.03 & 99.70 & 310.00 \\
\hline & 17 & 3.09 & 9.35 & 15.72 & 29.70 & 39.05 & 156.00 \\
\hline & 18 & 3.62 & 10.96 & 21.99 & 41.55 & 52.50 & 150.00 \\
\hline & 19 & 5.24 & 15.88 & 21.67 & 40.94 & 56.82 & 150.00 \\
\hline \multirow{2}{*}{$\begin{array}{c}\text { Private } \\
\text { house No. }\end{array}$} & 1 & 0.00 & 0.00 & 4.84 & 9.14 & 9.14 & 50.00 \\
\hline & 2 & 0.00 & 0.00 & 1.47 & 2.78 & 2.78 & 50.00 \\
\hline \multirow{14}{*}{$\begin{array}{c}\text { Institution } \\
\text { building } \\
\text { No. }\end{array}$} & 1 & 1.46 & 4.42 & 34.43 & 65.05 & 69.47 & 233.00 \\
\hline & 2 & 1.20 & 3.64 & 21.65 & 40.91 & 44.55 & 191.00 \\
\hline & 3 & 38.90 & 117.84 & 31.07 & 58.71 & 176.55 & 861.00 \\
\hline & 4 & 8.20 & 24.83 & 79.17 & 149.60 & 174.43 & 461.00 \\
\hline & 5 & 1.09 & 3.30 & 2.52 & 4.75 & 8.05 & 0.00 \\
\hline & 6 & 0.00 & 0.00 & 7.16 & 13.54 & 13.54 & 80.00 \\
\hline & 7 & 4.30 & 13.04 & 67.90 & 128.30 & 141.34 & 398.00 \\
\hline & 8 & 0.08 & 0.24 & 3.21 & 6.07 & 6.31 & 0.00 \\
\hline & 9 & 2.60 & 7.86 & 100.09 & 189.14 & 197.00 & 225.00 \\
\hline & 10 & 13.59 & 41.16 & 175.91 & 332.41 & 373.58 & 590.00 \\
\hline & 11 & 2.05 & 6.22 & 29.60 & 55.93 & 62.15 & 0.00 \\
\hline & 12 & 3.55 & 10.76 & 22.19 & 41.93 & 52.69 & 192.00 \\
\hline & 13 & 4.31 & 13.04 & 40.51 & 76.54 & 89.59 & 177.00 \\
\hline & 14 & 27.67 & 83.83 & 176.71 & 333.92 & 417.74 & 500.00 \\
\hline \multicolumn{2}{|l|}{ Total } & - & 797.93 & - & 2612.48 & 3410.41 & 8173.00 \\
\hline
\end{tabular}

The algorithm of calculations described in Figure 3 sums up the method of determining the heat consumption profile, which is based on the actual consumption data and can be used for further calculations or actions. 


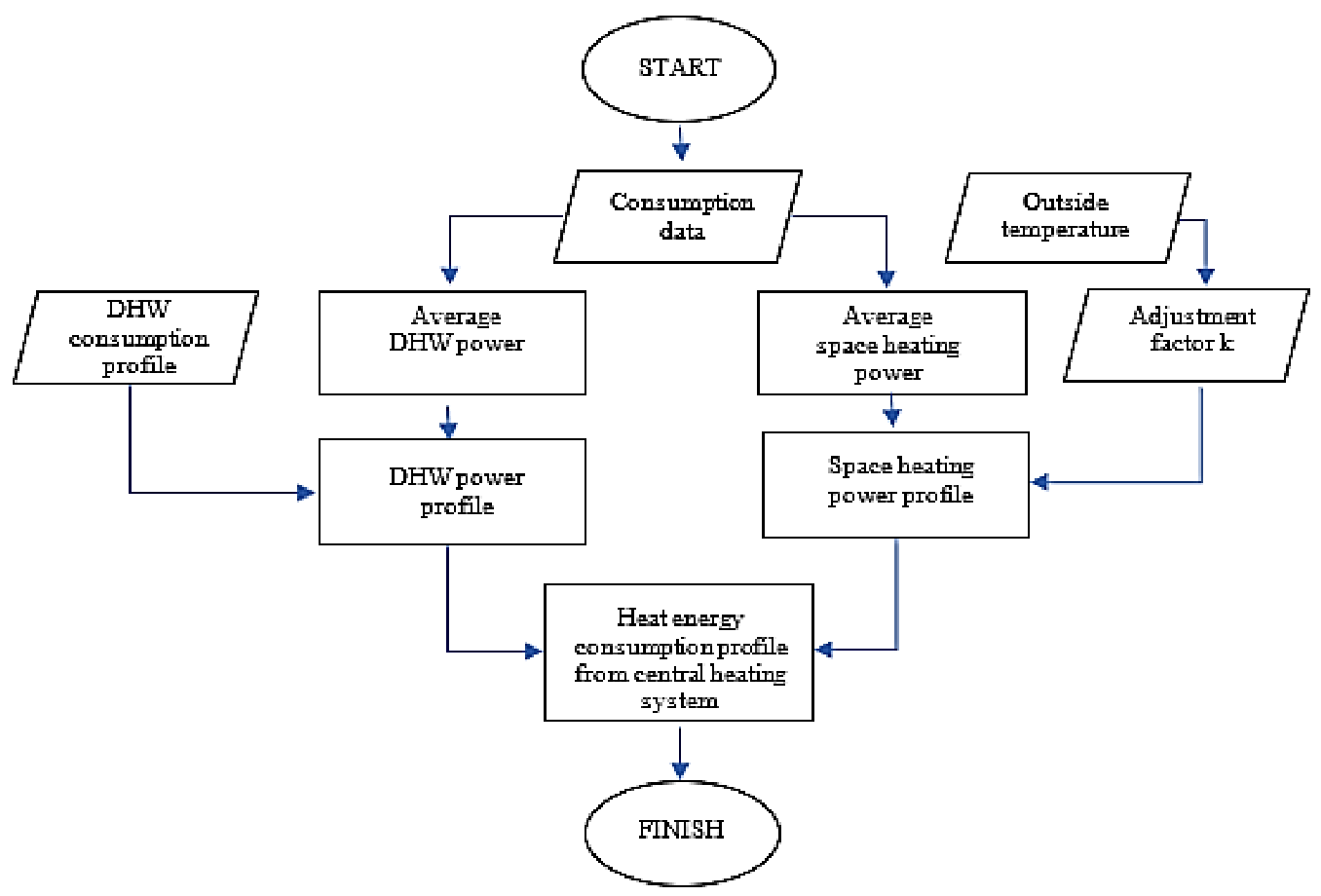

Fig. 3. Algorithm of calculations for determining heat consumption profile

\section{Conclusions}

The results of the calculations and the created thermal power consumption profile can be used to create overall description of the central heating grid and also to tune the supplier and consumer systems accordingly.

The calculations show that the consumption based maximal demanded power of the consumers is $3410 \mathrm{~kW}$, however, the connections' capacity and the registered power is $240 \%$ larger, which affirms that adjustments can be done to increase the overall efficiency.

Precision of the profile is reasonable, because the actual buildings' consumption data are used, but it can be raised, if additional local researches are done, which include research of the specific building's hot water consumption profile, also the outside air temperature effect on hot water operation and the time of the day effect on space heating.

\section{References}

[1] Distech controls. Datasheet TT-331. PDCSY-TT-331_TT-332, pp. 1-5.

[2] Budjko Ž. Investigation of The Domestic Hot Water Consumption in the Apartment Building. Construction Science, (ISSN 1407-7329), 2009, p. 8.

[3] Regulation No. 876, "Regulations for Supply and Use of Heat Energy", Cabinet of Ministers of Latvia, Paragraph 35, 2008.

[4] Yao R., Steemers K. A method of formulating energy load profile for domestic buildings in the UK. Energy and Buildings. 37, 2005, pp. 663-671. 